\title{
Effects of glucocorticoids on Fas gene expression in bovine blood neutrophils
}

\author{
Ling-Chu Chang, Sally A Madsen, Trine Toelboell, \\ Patty S D Weber and Jeanne L Burton
}

Immunogenetics Laboratory, Department of Animal Science, Michigan State University, East Lansing, MI 48824, USA

(Requests for offprints should be addressed to J L Burton; Email: burtonj@msu.edu)

\begin{abstract}
Blood neutrophils are extremely short-lived cells that are programmed for rapid apoptosis after differentiation in bone marrow. Recently, glucocorticoids have been shown to prolong survival of human and rodent neutrophils, but the mechanisms and implications for leukocyte homeostasis and health are unclear. In this study, we investigated the effects of endogenous and exogenous glucocorticoids on Fas expression in bovine neutrophils because Fas is a major death receptor that stimulates apoptosis in circulating cells. Our study subjects were four periparturient dairy cows whose blood concentrations of cortisol peaked at calving, 15 dexamethasone-treated steers and three untreated steers whose neutrophils were exposed to dexamethasone in vitro. Fas mRNA abundance changes in collected neutrophils were monitored numerous times relative to the in vivo glucocorticoid challenges, and the relationships between these data and circulating neutrophil counts were estimated by correlation analyses. Fas mRNA and protein abundance, caspase 8 activity, and survival of neutrophils in vitro were also monitored in the presence and absence of dexamethasone. In the periparturient cows, Fas mRNA abundance in circulating neutrophils showed a sharp decrease between calving and $12 \mathrm{~h}$ postpartum. Based on PROC CORR analysis (SAS), this correlated negatively with blood neutrophil count $(r=-0 \cdot 634$;
\end{abstract}

$P=0 \cdot 0009)$ and serum cortisol concentration $(r=-0 \cdot 659$; $P<0 \cdot 0001)$, but showed no relationship with serum progesterone or estradiol concentrations $(P \geq 0.09)$. Administration of dexamethasone to steers also caused a pronounced reduction in neutrophil Fas mRNA abundance that persisted for $12 \mathrm{~h}$ and correlated negatively with blood neutrophil count $(r=-0 \cdot 748 ; P=0 \cdot 0021)$. In vitro, dexamethasone caused dose-dependent loss of GR proteins from the cytosol of neutrophils concurrently with Fas mRNA downregulation, which was inhibited by the glucocorticoid receptor (GR) antagonist, RU486. Dexamethasone treatment of cultured neutrophils also reduced surface Fas expression, spontaneous and sFasL-induced caspase 8 activity, and rate of apoptosis in the cells. Taken together, these in vivo and in vitro results suggest that glucocorticoids inhibit Fas expression in bovine blood neutrophils via GR activation, possibly contributing to the cells' increased longevity in culture and the pronounced neutrophilia observed in parturient cows and hormonetreated steers. We thus conclude that glucocorticoidactivated GR may change the homeostasis of circulating neutrophils, in part through its negative effects on Fas gene expression and downstream apoptosis signaling pathways. Journal of Endocrinology (2004) 183, 569-583

\section{Introduction}

Neutrophils are one of the most important immune cells regulating acute inflammation after trauma and infection. The best-known function of neutrophils is their bactericidal activity, which is accomplished by release of reactive oxygen species and lytic enzymes following the phagocytosis-induced respiratory burst after the cells migrate into inflamed and infected tissues. The onset of apoptosis shortly after phagocytosis impairs neutrophil function, in turn limiting damage to other healthy cells in the vicinity of infection foci (Whyte et al. 1993, Haslett 1999).
Unlike inflammatory neutrophils that live for $24-48 \mathrm{~h}$ in infected tissues, blood neutrophils have a short life span of $6-12 \mathrm{~h}$ in the circulation. This is because these cells are genetically programmed to undergo apoptosis as soon as they terminally differentiate in bone marrow (Kuijpers 2002). The tight regulation of blood neutrophil life span via apoptosis rather than necrosis is critical to avoid systemic inflammation and blood vessel damage (Sendo et al. 1996). However, the life span of blood neutrophils can be extended when circulating concentrations of cytokines and certain hormones are elevated. For example, colonystimulating factors (G-CSF and GM-CSF), cytokines (interleukin (IL)-1 $\beta$, IL-2, IL-6, IL-8 and tumor necrosis 
factor (TNF)- $\alpha$ ), and glucocorticoids can delay apoptosis for up to $48 \mathrm{~h}$ in human and rodent neutrophils (Cox 1995, Liles et al. 1995, 1996, Meagher et al. 1996, Nittoh et al. 1998, Daffern et al. 1999, Webb et al. 2000). The main mechanism of prolonged neutrophil survival by cytokines appears to be activation of $\mathrm{NF}-\kappa \mathrm{B}$ and its subsequent transactivation of numerous proinflammatory genes that are also antiapoptotic (Moulding et al. 1998, 2001, Dibbert et al. 1999). The cytokine-induced delay of apoptosis of neutrophils recruited into inflammatory foci may enhance phagocytosis of infectious pathogens (Coxon et al. 1999). However, the mechanisms explaining the prolonged survival of neutrophils mediated by glucocorticoids are not known. It is also not clear why glucocorticoids induce neutrophil survival, because the hormones also depress neutrophil migration and bactericidal activity (reviewed by Heasman et al. 2003).

Neutrophil apoptosis occurs through two main pathways (reviewed by Fanning et al. 1999), one that is mediated via exogenous death receptor signaling (Liles et al. 1996) and the other that occurs spontaneously through mitochondrial membrane changes under the influence of Bcl-2 family proteins (Lin et al. 1996). In the current study, we chose to examine the main exogenous death receptor of neutrophils, Fas. Fas (also called CD95/APO-1) is a type I membrane glycoprotein belonging to the TNF-receptor superfamily of molecules. Death signals are initiated in neutrophils when Fas becomes trimerized upon interaction with its ligand, Fas ligand (FasL). FasL activation of Fas recruits numerous death-domain-containing proteins to the cytoplasmic death domain of Fas, and these act as adaptor molecules for the ultimate recruitment and activation of caspase 8 to initiate apoptosis signaling via a variety of mechanisms (reviewed by Schulze-Osthoff $e t$ al. 1998, Sharma et al. 2000). Ultimately, caspase 8 activation results in cleavage of proteins involved in cytoskeletal maintenance and DNA repair, leading to membrane blebbing, nuclear condensation and collapse, and irreversible cell death (reviewed by Robertson 2000, Zimmermann et al. 2001). Fas and FasL are constitutively coexpressed in human blood neutrophils, rendering the cells highly sensitive to apoptosis (Liles et al. 1996).

Several studies report that glucocorticoids attenuate apoptosis in human and rat neutrophils (Cox 1995, Liles et al. 1995, 1996, Meagher et al. 1996, Nittoh et al. 1998). However, the mechanisms of survival induction by glucocorticoids are not known, and specific effects of glucocorticoids on Fas expression have not been reported. We hypothesized in the current study that glucocorticoids downregulate Fas expression in neutrophils by activating the cells' glucocorticoid receptors (GR). Our results show that glucocorticoids cause dose-dependent and GRmediated downregulation of Fas gene expression in bovine blood neutrophils, with corresponding reductions in surface Fas expression, caspase 8 activity and rate of apoptosis in vitro, and increases in circulating cell numbers in vivo.

\section{Materials and Methods}

\section{Animals and sample collections}

Experiment 1: periparturient cows Four periparturient Holstein cows in first pregnancy were used to determine whether Fas mRNA expression in neutrophils changes during parturition in correlation with serum steroid concentrations and circulating neutrophil numbers. The cows were housed at Michigan State University's (MSU) Dairy Teaching and Research facility and cared for according to standard operating procedures there (MSU animal use approval no. 03/99-031-00). Blood samples were collected on days $-8,-4,0,0 \cdot 25,0 \cdot 5,1,1 \cdot 5,2$ and 7 relative to parturition (on day 0 ), as described in a previous study (Weber et al. 2001). Blood designated for neutrophil isolations was collected in acid citrate dextrose (ACD) anticoagulant, while that used for serum steroid assays was collected into evacuated tubes containing no anticoagulant. All blood samples were placed on ice immediately after collection.

\section{Experiment 2: dexamethasone-treated steers Fifteen} Holstein steers (4-5 months of age) castrated at 1 month of age were used for an in vivo glucocorticoid challenge study. The animals were housed in individual pens at the MSU Dairy Teaching and Research facility, fitted with jugular catheters (Weber et al. 2004), and cared for according to standard operating procedures (MSU animal use approval no. 06/01-092-00). Steers were randomly allocated to five blood collection groups with three steers per group. One group served as untreated controls, and its blood samples were called ' 0 h'. Steers in the other four groups were treated with various doses of dexamethasone (Azium; Schering Plough, Animal Health, Kenilworth, NJ, USA), each dose administered intramuscularly at $0.10 \mathrm{mg} / \mathrm{kg}$ body weight. In the 3-h and 6-h groups, dexamethasone was administered once at $0 \mathrm{~h}$, and blood samples were collected 3 and $6 \mathrm{~h}$ later respectively. In the 12-h group, dexamethasone was administered twice at 0 and $6 \mathrm{~h}$, and blood samples were collected $12 \mathrm{~h}$ after the 0 -h dose. In the 24-h group, dexamethasone was administered thrice, at 0,6 and $12 \mathrm{~h}$, and blood samples were collected $24 \mathrm{~h}$ after the $0-\mathrm{h}$ dose. All blood samples were collected through the jugular catheters into ACD-containing tubes, which were placed on ice immediately.

\section{Experiment 3: dexamethasone treatment of isolated} neutrophils Neutrophils were isolated from the blood of three additional donor steers (MSU animal use approval no. 06/01-092-00) as needed for use in in vitro experiments. These animals were not treated with dexamethasone. Isolated blood neutrophils (see below) were cultured in basic medium (RPMI-1640 medium; Invitrogen Life Technologies, Carlsbad, CA, USA) containing $25 \mathrm{mM}$ HEPES, 1\% BSA (Sigma) and 25 units $/ \mathrm{ml}$ 
penicillin-25 $\mu \mathrm{g} / \mathrm{ml}$ streptomycin (Invitrogen), and treated with varying doses of dexamethasone $\left(0,10^{-9}, 10^{-7}\right.$ or $\left.10^{-5} \mathrm{M}\right)$ as described below. Where indicated, additional cultures of identical cells were pretreated for $10 \mathrm{~min}$ with RU486 (10 ${ }^{-4}$ M; Sigma) prior to addition of dexamethasone. Neutrophils intended for RNA and protein isolations were seeded into sterile, $50 \mathrm{ml}$, conical tubes $(10 \mathrm{ml}$ of $5 \times 10^{6}$ cells $/ \mathrm{ml}$ ) and incubated for $4 \mathrm{~h}$ (Forma Scientific Model 420; Thermo Electron Corporation, Marietta, $\mathrm{OH}$, USA) at $39^{\circ} \mathrm{C}$ (normal body temperature for cattle) and a shake speed of 90 r.p.m. After incubation, the cells were split into two aliquots and pelleted for lysis in either TRIzol Reagent (Invitrogen) or in a buffer containing protease inhibitors (see below). Neutrophils intended for apoptosis phenotyping were seeded into wells of culture plates, and treated as described below.

\section{Assay protocols}

Radioimmunoassay of serum steroids In experiment 1 , sera were harvested $\left(1000 \mathrm{~g}\right.$ at $4{ }^{\circ} \mathrm{C}$ for $\left.20 \mathrm{~min}\right)$ from blood samples that were clotted overnight at $4{ }^{\circ} \mathrm{C}$, and stored at $-20{ }^{\circ} \mathrm{C}$ until assayed in duplicate for cortisol $(\mu \mathrm{g} / \mathrm{dl})$, progesterone $(\mathrm{ng} / \mathrm{ml})$ and estradiol $(\mathrm{pg} / \mathrm{ml})$ (Coat-ACount RIA kits; Diagnostic Products Corporation, Los Angeles, CA, USA). As described in Weber et al. (2001), cortisol and progesterone assays were performed on single days (intra-assay CVs of $<9 \%$ ). Aliquots of sera for estradiol determination were extracted with diethyl ether before being assayed (intra-assay $\mathrm{CV}=6 \cdot 1 \%$; inter-assay $\mathrm{CV}=15 \cdot 1 \%)$.

\section{Neutrophil differentials in whole blood}

Aliquots of whole blood collected from cows and steers in experiments 1 and 2 were subjected to flow cytometric analysis (FACScalibur Flow Cytometer and Cell Quest software; Becton Dickinson, San Jose, CA, USA) to determine the percentages of neutrophils (of total leukocytes) in each sample based on the cells' characteristic forward- and $90^{\circ}$-light scattering properties (Weber et al. 2001).

\section{Purification of bovine blood neutrophils}

Neutrophils were isolated from whole blood of all animals by Percoll density gradient centrifugation (Weber et al. 2001, 2004). Neutrophil purity was $\geq 95 \%$ (based on flow cytometric analysis, described above), and viability was $\geq 97 \%$ (based on propidium iodide staining of nuclei). The minor population of contaminating cells were eosinophils.

\section{Extraction of neutrophil total RNA}

Neutrophil samples from all three experiments that were lysed in TRIzol Reagent $\left(1 \times 10^{7}\right.$ cells $\left./ \mathrm{ml}\right)$ were stored at $-80{ }^{\circ} \mathrm{C}$ until total RNA isolations were performed (according to the manufacturer's instructions). Total RNA concentration and purity were determined with a DU-650 spectrophotometer (Beckman Coulter, Scaumburg, IL, USA) and the 260 and $280 \mathrm{~nm}$ readings.

\section{Northern and slot blotting}

In experiment 1 , Fas mRNA abundance in neutrophils from parturient cows was quantified by slot blot analysis. The Fas cDNA probe used was 517 base pairs (bp) in length and generated by PCR from bovine total leukocyte cDNA template. The forward primer was $5^{\prime}$ - ATG GGC TAG AAG TGG AAC AAA AC- $3^{\prime}$ and the reverse primer was $5^{\prime}$ - TTC TTC CCA TGA CTT TGA TAC C-3'. The PCR mixture contained $20 \mathrm{mM}$ Tris- $\mathrm{HCl}$, $50 \mathrm{mM} \mathrm{KCl}, 0 \cdot 2 \mathrm{mM}$ of each dNTP, $3.0 \mathrm{mM} \mathrm{MgCl}$, $0 \cdot 2 \mathrm{nM}$ of each primer, $100 \mathrm{ng}$ template cDNA and $2 \cdot 0$ units of Taq DNA polymerase (Invitrogen) in a final volume of $50 \mu$ l. PCR reactions were carried out in a RoboCycler Gradient 96 (Stratagene, La Jolla, CA, USA) under the following conditions: hot start at $95^{\circ} \mathrm{C}$ for 3 min; 35 cycles of PCR amplification at $95^{\circ} \mathrm{C}$ for $30 \mathrm{~s}$, $47^{\circ} \mathrm{C}$ for $30 \mathrm{~s}$ and $72{ }^{\circ} \mathrm{C}$ for $30 \mathrm{~s}$; and final extension at $72{ }^{\circ} \mathrm{C}$ for $10 \mathrm{~min}$. The PCR amplification product was analyzed by agarose gel electrophoresis $(1.8 \%)$ and visualized as a single bright band after ethidium bromide staining. This product was ligated into pGEM-T Easy (Promega) and the recombinant plasmid transformed into JM109 competent cells (Promega). The 517 bp insert was DNA sequenced and shown to be $97 \%$ homologous to the published sequence for bovine Fas (Yoo et al. 1996) (GenBank accession no. NM_174662). The cDNA insert was excised from plasmid DNA with EcoRI (New England Biolabs, Beverly, MA, USA), gel purified (Wizard Kit, Promega) and visualized as a single bright band on a $1.8 \%$ agarose gel stained with ethidium bromide for use in Northern blot assessment. This was done with $8 \mu \mathrm{g}$ of neutrophil total RNA from one cow at 8 days prepartum (experiment 1) for electrophoresis, according to the protocol in Weber et al. (2001). Slot blot analysis (Weber et al. 2001) was then performed to quantify Fas mRNA abundance in all neutrophil samples of experiment 1 . Briefly, $5 \mu \mathrm{g}$ of each RNA sample was spotted on a nylon membrane, probed with ${ }^{32} \mathrm{P}-$ labeled Fas cDNA, stripped and reprobed with ${ }^{32} \mathrm{P}-$ labeled $\beta$-actin cDNA. Slot intensities were determined by scanning densitometry (GS-710 Calibrated Imaging Densitometer and MultiAnalyst Software; BioRad), and Fas mRNA abundance was recorded as the density ratio Fas: $\beta$-actin for each slot.

\section{Quantitative real-time reverse transcription polymerase chain reaction (Q-RT-PCR)}

In experiments 2 and 3, Fas and (or) GR $\alpha$ mRNA abundance was quantified by Q-RT-PCR, as described by Madsen et al. (2004). An amount of $2 \mu \mathrm{g}$ total RNA per 
sample was used for cDNA synthesis (oligo(dT) ${ }_{12-18}$ primer (Invitrogen) and Superscript II RNase $\mathrm{H}^{-}$-Reverse Transcriptase (Invitrogen)), and the Q-RT-PCR assay was performed in duplicate with $2.5 \mathrm{ng}$ starting cDNA per sample and the SYBR Green PCR Master Mix system for detection (Perkin Elmer Applied Biosystems, Forster City, CA, USA). Gene-specific primers for bovine Fas, GR $\alpha$ and $\beta$-actin were designed with Primer Express Software (Perkin Elmer Applied Biosystems) and synthesized at a commercial facility (Qiagen-Operon, Alameda, CA, USA). For Fas, the primers were as follows: forward, 5'-TGT AAA GTC AGC TTA TAC ACA GCA GAA GT-3'; reverse, 5'-GTG GGC TGC CGC CTA TG-3' (product length $104 \mathrm{bp}, \mathrm{Tm}=81{ }^{\circ} \mathrm{C}$ ). For $\mathrm{GR} \alpha$, the primers were as follows: forward, $5^{\prime}$-TGT GGT TTA AAG AGG GCC AAG A-3'; reverse, 5'-TTC TAC GTT CCC ATC ACT GAA AAG-3' (product length= $74 \mathrm{bp}, \mathrm{Tm}=78^{\circ} \mathrm{C}$ ). For $\beta$-actin, the primers were as follows: forward, $5^{\prime}$-CGC CAT GGA TGA TGA TAT TGC-3'; reverse, 5'- AAG CCG GCC TTG CAC AT $-3^{\prime}$ (product length $=66 \mathrm{bp}, \mathrm{Tm}=84^{\circ} \mathrm{C}$ ). The resulting Fas and GR $\alpha$ mRNA abundance data were normalized against $\beta$-actin mRNA abundance, and the gene expression changes induced by the various treatments were determined by the $2^{-\Delta \Delta C} \mathrm{~T}$ method of Livak and Schmittgen (2001). In experiment 2, data from the $0-\mathrm{h}$ samples were used as the calibrators in $2^{-\Delta \Delta C} \mathrm{~T}$ against which all other samples were compared. In experiment 3, untreated neutrophils at $0 \mathrm{~h}$ were used as the calibrators in the $2^{-\Delta \Delta C} \mathrm{~T}$ analyses.

\section{Immunoblot analysis of glucocorticoid receptor proteins}

Methods used to isolate neutrophil cytosolic fractions and perform the immunoblot assay are detailed in Weber et al. (2004). Lanes of 10\% SDS-PAGE gels were loaded with $40 \mu \mathrm{g}$ cytosolic total protein from steer neutrophils treated in vitro with $0,10^{-9}, 10^{-7}$ or $10^{-5} \mathrm{M}$ of dexamethasone (experiment 3). GR abundance in each sample was detected with an antirabbit GR polyclonal antibody $(0.5 \mu \mathrm{g} / \mathrm{ml})$ (PA1-511A; Affinity Bioreagent, Golden, CO, USA) that recognizes both alpha $(\mathrm{GR} \alpha)$ and beta $(\mathrm{GR} \beta)$ isoforms of GR. A goat antirabbit immunoglobulin $(\mathrm{Ig}) \mathrm{G}_{1}$ horseradish peroxidase-conjugate (Pierce, Rockford, IL, USA) was used as the detection antibody. Immunoblots were developed with the SuperSignal West Pico chemiluminescent substrate system (Pierce). Membranes were stripped and reprobed with an anti- $\beta$ actin primary antibody (Abcam, Cambridge, UK), with goat antimouse $\operatorname{IgG}_{1}$ horseradish peroxidase-conjugate (Bethyl, Montgomery, TX, USA) as the detection antibody, to check equal loading of samples across lanes.

\section{Fluorescence-activated flow cytometry}

Changes in neutrophil surface expression of Fas protein under in vitro treatment with dexamethasone were monitored by immunostaining and fluorescence-activated flow cytometry (FACSCalibur Flow Cytometer; Becton Dickinson). Purified neutrophils from steers of experiment 3 were cultured in duplicate in basic medium that contained $1 \%$ fetal bovine serum (FBS), in the absence or presence $10^{-7} \mathrm{M}$ dexamethasone, for 0,4 or $8 \mathrm{~h}$ (in moist $5 \%$ $\mathrm{CO}_{2}$ air at $\left.39^{\circ} \mathrm{C}\right)$. An anti-Fas polyclonal antibody (1:200 dilution; Stressgen, British Columbia, Canada) and PEconjugated secondary antibody (1:400 dilution) (Molecular Probes, Eugene, OR, USA) were used for immunostaining, which was done according to our published method (Weber et al. 2004). Assay-negative controls included unstained cells and cells treated with only the secondary antibody. Data from 10000 cells per sample were collected. Changes in surface Fas expression were determined from histogram plots of PE-fluorescence intensity, as the percentage (\%) of $\mathrm{Fas}^{+}$cells. These raw data were then used to calculate the percent change $(\% \Delta)$ in $\mathrm{Fas}^{+}$cells for dexamethasone-treated and -untreated cells at 4 and $8 \mathrm{~h}$ relative to untreated cells at $0 \mathrm{~h}$.

\section{Caspase 8 activity}

Caspase 8 activity was determined with the ApoAlert Caspase-8 Colormetric Assay Kit (BD Biosciences, Palo Alto, CA, USA), according to the manufacturer's recommended procedure. Briefly, $3 \times 10^{6}$ cells per well were seeded into $24-w e l l$ plates and cultured in basic medium containing $1 \%$ FBS in the absence or presence of $10^{-7} \mathrm{M}$ dexamethasone for $4 \mathrm{~h}$. Then, cells were stimulated with $0,10,50$ or $100 \mathrm{ng} / \mathrm{ml}$ of recombinant sFasL (Alexis, San Diego, CA, USA) for an additional $3 \mathrm{~h}$. The assay control was cells pretreated for $30 \mathrm{~min}$ with a caspase 8 inhibitor (50 $\mu \mathrm{M}$ of z-IETD-fmk; Calbiocem, La Jolla, CA, USA) before $s F a s L$ stimulation. After incubation, cells were centrifuged at $500 \mathrm{~g}$ for $5 \mathrm{~min}$ at $4{ }^{\circ} \mathrm{C}$, and washed twice with cold PBS, pH 7·2. Cells were suspended in $50 \mu \mathrm{l}$ chilled cell lysis buffer and incubated on ice for $10 \mathrm{~min}$. Cellular debris was separated by centrifugation $(13000 \boldsymbol{g}$, for $10 \mathrm{~min}$ at $4{ }^{\circ} \mathrm{C}$ ). An equal amount of $2 \mathrm{X}$ Reaction Buffer/DTT mix containing the labeled Caspase 8 substrate (IETD-pNA; final concentration of $200 \mu \mathrm{M}$ ), was added to the supernatant and incubated at $37^{\circ} \mathrm{C}$ for $3 \mathrm{~h}$. Substrate cleavage with pNA accumulation and accompanying color change was monitored by a microplate reader $(405 \mathrm{~nm})$ (Benchmark Microplate Readerwas, Bio$\mathrm{Rad})$. Protein determinations were made for each sample with the Bradford Assay Protein Detection Kit (Bio-Rad), and caspase 8 activity was recorded as optical density $405 \mathrm{~nm}$ per $\mathrm{mg}$ protein (OD/mg protein).

\section{Annexin V-FITC and propidium iodide staining}

Apoptosis status of cultured neutrophils from steers of experiment 3 was assessed by two-color fluorescenceactivated flow cytometric analysis of cells stained at various 
incubation times with Annexin V-FITC and propidium iodide (PI). Briefly, neutrophils were reconstituted at $1 \times 10^{7}$ cells $/ \mathrm{ml}$ in basic culture medium containing $1 \%$ FBS, and $0.1 \mathrm{ml}$ per well was seeded into 96-well cell culture plates (Fisher Scientific, Pittsburgh, PA, USA) and incubated in moist $5 \% \mathrm{CO}_{2}$ air at $39^{\circ} \mathrm{C}$ for 7,12 or $24 \mathrm{~h}$. After incubation, cells were centrifuged at $500 \boldsymbol{g}$ for 5 min at $4{ }^{\circ} \mathrm{C}$, washed twice with cold PBS, pH 7.2, and stained with FITC-conjugated Annexin V and PI by the protocol contained in a commercial kit (Annexin V-FITC Apoptosis Detection Kit; BD Biosciences Pharmingen, San Diego, CA, USA). Cells were then transferred to $5 \mathrm{ml}$ polystyrene round-bottom tubes (Becton Dickinson), and two-color data were acquired for 10000 cells per sample (FACSCaliber flow cytometer and Cell Quest software; Becton Dickinson). Quadrants were set on resulting density plots, effectively separating Annexin $\mathrm{V}^{-} / \mathrm{PI}^{-}$nonapoptotic cells (lower left quadrant) from Annexin $\mathrm{V}^{+} / \mathrm{PI}^{-}$ early apoptotic cells (lower right quadrant), AnnexinV $\mathrm{V}^{+} /$ $\mathrm{PI}^{+}$late apoptotic cells (upper right quadrant) and Annexin $\mathrm{V}^{-} / \mathrm{PI}^{+}$necrotic cells (upper left quadrant).

\section{Statistical analysis}

Before analyses, data sets were checked for normality of their distributions. All data were normally distributed and thus analyzed in their raw form, using the PROC MIXED function of SAS and including Tukey's adjustment for multiple comparisons (SAS Institute 1996). Stated differences between observations were declared when $P<0 \cdot 05$. Data presented in figures are time or treatment leastsquares means \pm S.E.M. Pearson product moment correlations between neutrophil Fas mRNA abundance and blood cortisol concentrations, or percent neutrophils in experiments 1 and 2 were computed by the PROC CORR function of SAS (SAS Institute 1990).

\section{Results}

\section{Experiment 1: periparturient cows}

Figure 1A shows that our Fas cDNA probe recognized two district transcripts in bovine blood neutrophils (approximately 1.7 and $2.9 \mathrm{~kb}$ ) that were similar in size to those reported in numerous human cell lines (Nambu et al. 1998, O'Donnell et al. 1999). We suspect that the $2.9 \mathrm{~kb}$ transcript represents a primary, unprocessed Fas mRNA, while the $1.7 \mathrm{~kb}$ transcript represents fully processed Fas mRNA. In a preliminary experiment, we confirmed that both transcripts were downregulated in neutrophils of a dexamethasone-treated steer (data not shown), and thus we proceeded with slot blot analysis of Fas mRNA abundance in neutrophils of the periparturient cows. This work showed that parturition caused a pronounced decrease $(P<0 \cdot 05)$ in Fas total mRNA, which reached nadir between days 0 and 0.5 and began to return to precalving levels by day 2 (Fig. 1B). The scatter plots in Fig. 2 show that Fas mRNA abundance was negatively correlated with serum cortisol concentrations $(r=-0.659$; $P<0.0001$; Fig. 2A) and with percent neutrophils in blood of the periparturient cows $(r=-0.634 ; P=0.0009$; Fig. 2B). Insignificant correlations were found between Fas mRNA abundance and the concentrations of serum estradiol $(r=0.05 ; P=0.78)$ or progesterone $(r=-0.304$; $P=0 \cdot 09)$ (data not shown).

\section{Experiment 2: dexamethasone-treated steers}

To test further the possible relationship between elevated blood glucocorticoid concentration and Fas gene expression in neutrophils, steers of experiment 2 were treated with various doses of dexamethasone and Fas mRNA abundance, and monitored by Q-RT-PCR. As shown in Fig. 3A, levels of Fas mRNA were decreased $(P<0 \cdot 05)$ to nadir in the 6 -h group $(79 \cdot 3 \pm 2 \cdot 3 \%)$ and the 12 -h group $(86 \cdot 4 \pm 2 \cdot 8 \%)$ relative to levels observed in the $0-h$ group. Overall, Fas mRNA abundance was negatively correlated with percentage of neutrophils in blood of these steers $(r=-0.748 ; P=0.002$; Fig. $3 \mathrm{~B})$.

\section{Experiment 3: dexamethasone treatment of isolated neutrophils}

Dexamethasone treatment in vitro caused dose-dependent downregulation of Fas mRNA abundance in neutrophils isolated from normal steers of experiment 3 (Fig. 4A). At the same time, dexamethasone treatment caused dosedependent loss of cytosolic GR $\alpha$ proteins in the neutrophils (representative immunoblot shown in Fig. 4B) without affecting the abundance of GR $\alpha$ mRNA (data not shown). Cytosolic expression of GR $\beta$ protein was not influenced by dexamethasone treatment (Fig. 4B). Inhibition of Fas gene expression by in vitro dexamethasone treatment was reversed when the neutrophils were pretreated with RU486 (Fig. 5). Fas protein expressed on the surface of bovine neutrophils was also decreased by dexamethasone treatment in vitro (Fig. 6). Dexamethasoneinduced decreases in Fas mRNA and protein appeared to be relevant because the steroid also reduced spontaneous and sFasL-induced caspase 8 activation (Fig. 7A and B) and the rate of apoptosis (representative two-color density dot plots shown in Fig. 8) in treated neutrophils.

\section{Discussion}

The most significant findings of this study are as follows: 1 . Fas gene expression in circulating bovine neutrophils changed in relationship to changing blood concentrations of endogenous and exogenous glucocorticoids; 2. Fas mRNA abundance correlated with blood neutrophil counts during bovine parturition and after glucocorticoid 
$\mathbf{A}$

\section{Fas}

$2.9 \mathrm{~kb}$

B

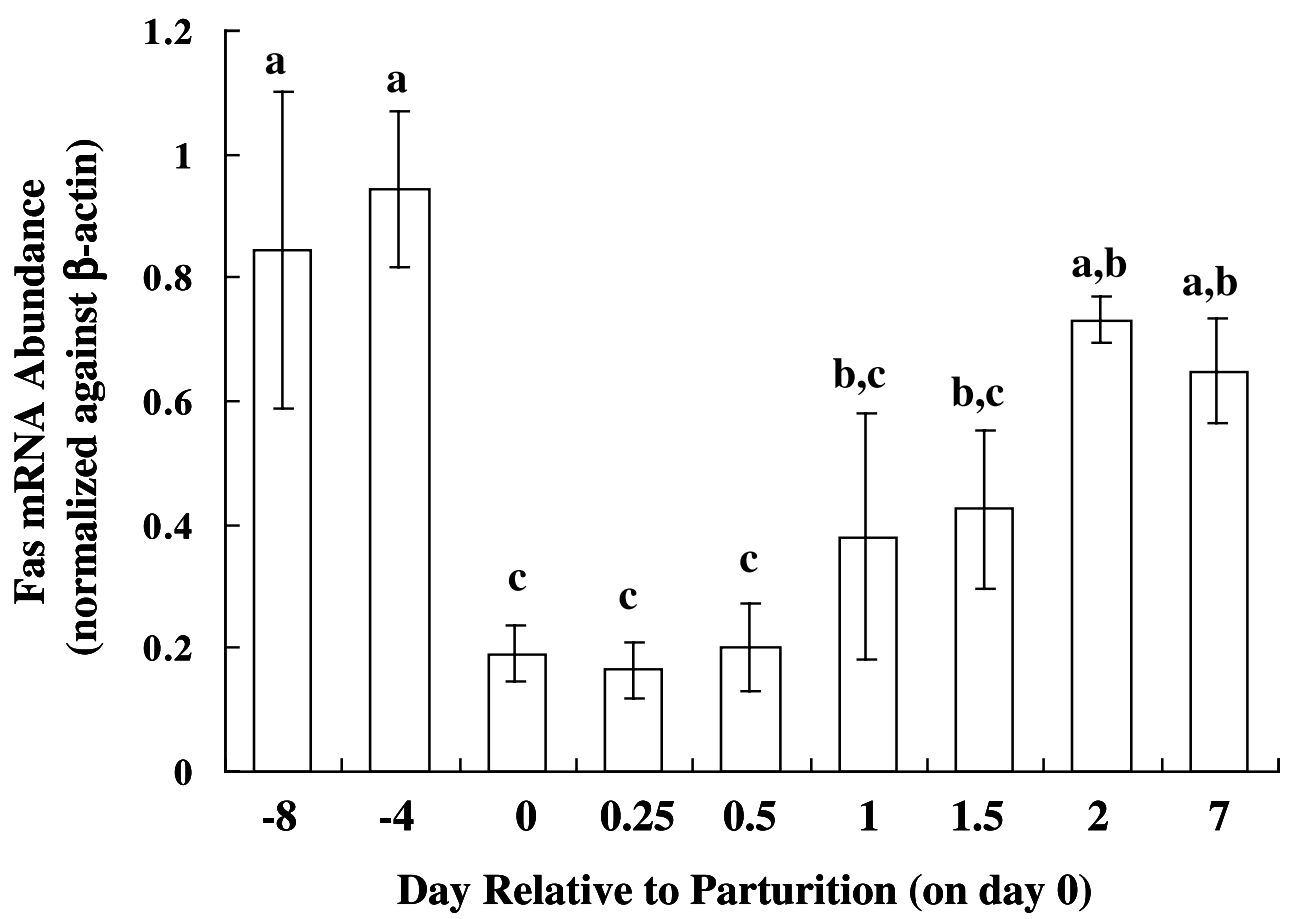

Figure 1 Fas mRNA abundance in blood neutrophils from periparturient cows. Fas mRNA abundance was decreased in bovine blood neutrophils for 1.5 days after parturition. (A) The 517 bp Fas cDNA probe developed for this study hybridized with two transcripts of 1.7 and $2.9 \mathrm{~kb}$ in bovine blood neutrophils. (B) Blood neutrophils were isolated from four periparturient cows on days $-8,-4,0,0 \cdot 25,0 \cdot 5,1,1 \cdot 5,2$ and 7 relative to parturition (day 0 ). Fas mRNA abundance was analyzed by slot blot using the cDNA probe shown (A). The blots were stripped and reprobed with $\beta$-actin CDNA as the normalizing gene. Bars with different letters are significantly different at $P<0 \cdot 05$.

administration to cattle; 3 . glucocorticoid-induced downregulation of Fas gene and protein expression in vitro was associated with reduced activity of spontaneous and sFasLinduced caspase 8 activity and rate of apoptosis in cultured bovine neutrophils; 4. glucocorticoid-induced Fas downregulation in bovine blood neutrophils involved hormoneactivated GR $\alpha$. Our results thus implicate inhibited Fas expression and downstream apoptosis signaling as one possible mechanism to account for the reported ability of glucocorticoids to extend the survival of blood neutrophils (Cox 1995, Liles et al. 1995, 1996, Meagher et al. 1996, Nittoh et al. 1998, Daffern et al. 1999).

While GR exists in at least two isoforms (GR $\alpha$ and GR $\beta$ ), only GR $\alpha$ has known capacity for ligand binding 

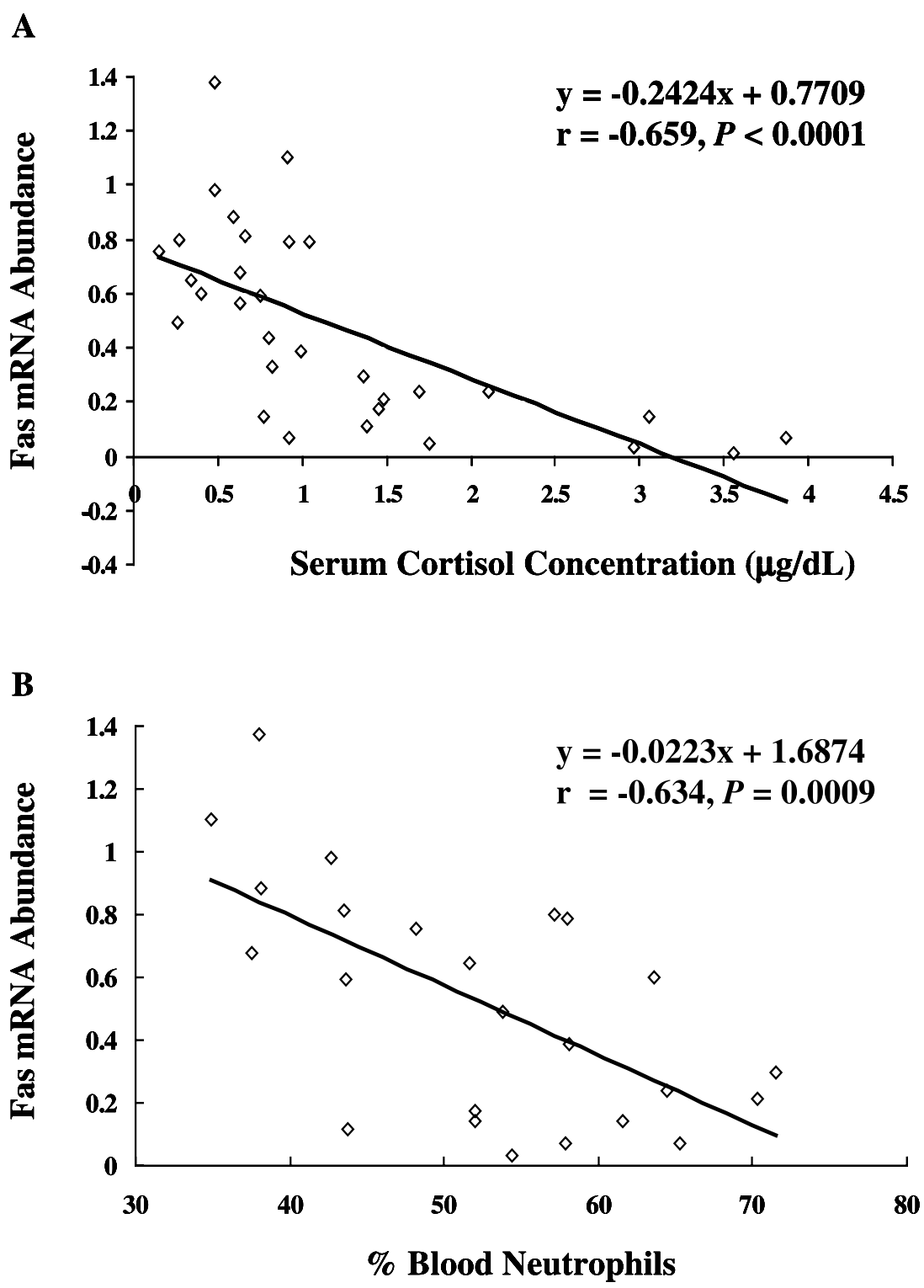

Figure 2 Fas mRNA abundance in blood neutrophils was negatively correlated with serum cortisol concentrations (A) and percentage of blood neutrophils (B) during parturition in dairy cows. Blood samples for these correlation analyses were from four parturient cows collected on days $-8,-4,0,0 \cdot 25,0 \cdot 5,1,1 \cdot 5,2$ and 7 relative to parturition (day 0). Serum cortisol was determined by RIA. Percentage of neutrophils was determined flow cytometrically.

(Bamberger et al. 1996, Kino et al. 2001). Like the bovine neutrophils we studied here (Fig. 4B), human neutrophils are reported to express GR $\alpha$ and GR $\beta$ (Strickland et al. 2001, Pujols et al. 2002). However, neutrophils are sensitive to glucocorticoids because of GR $\alpha$ expression (Weyts et al. 1998). In most resting cells, GR $\alpha$ is primarily located in the cytoplasm, where it complexes with heat-shock proteins to maintain a high-affinity hormone-binding state (Bamberger et al. 1996). Upon glucocorticoid binding,
GR $\alpha$ dissociates from this complex and translocates into nuclei, where it initiates transcription by binding to glucocorticoid-response elements (GRE) in promoters of inducible target genes, and by interacting positively with transcriptional coactivators of the genes (Bamberger et al. 1996, Collingwood et al. 1999, De Bosscher et al. 2003). However, GR $\alpha$ can also bind to negative GREs (nGRE), resulting in inhibition of gene transcription (Droulin et al. 1989). In addition to nGRE binding, GR $\alpha$ can halt 

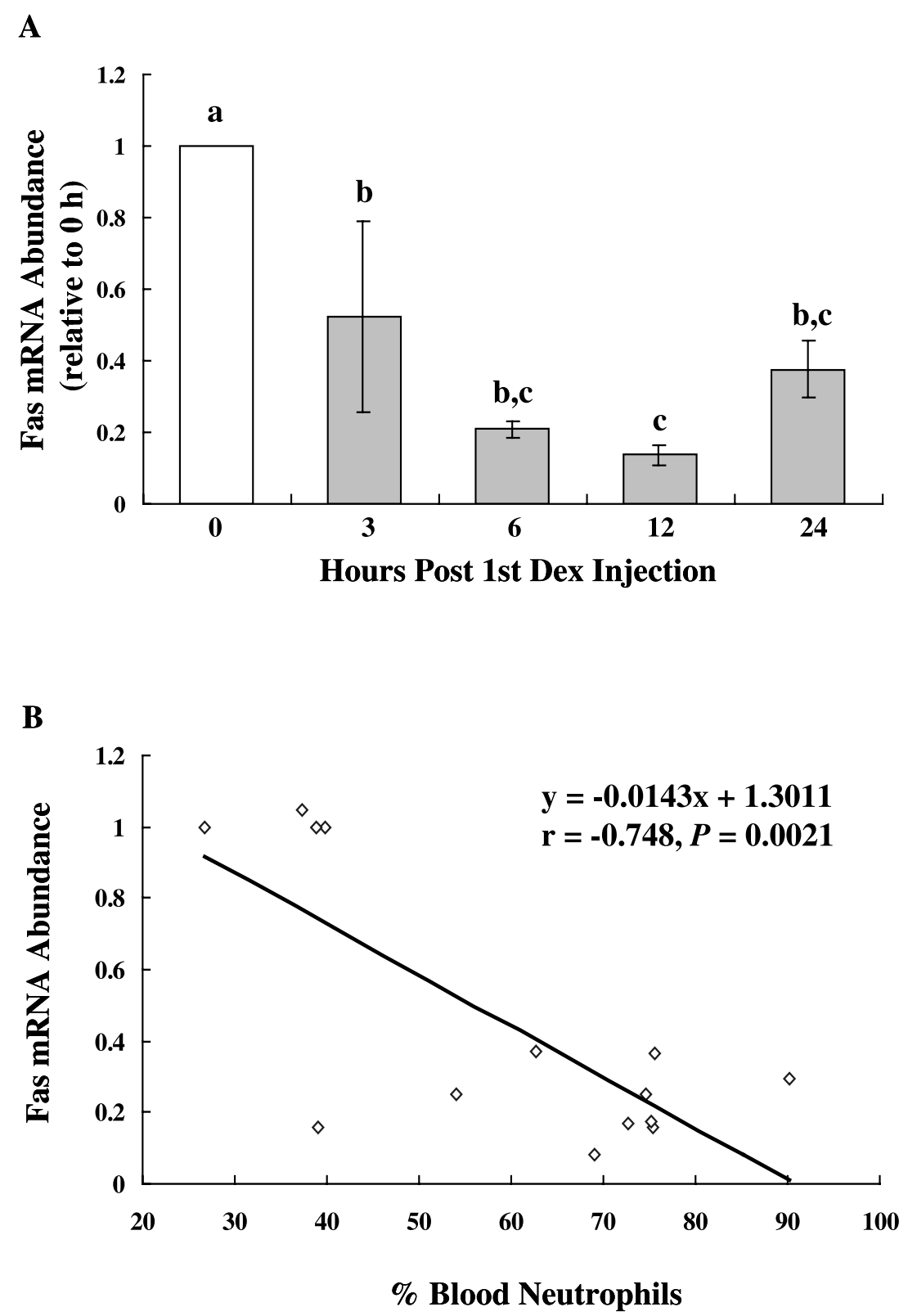

Figure 3 Fas mRNA abundance in blood neutrophils from dexamethasone-treated steers correlated negatively with percentage of circulating neutrophils. Dexamethasone (Dex) administered to steers caused a pronounced decrease in Fas mRNA abundance in blood neutrophils. The neutrophils were collected from 15 steers ( $n=3$ per time group) at 0,3 , 6,12 and $24 \mathrm{~h}$ after dexamethasone injection $(0 \cdot 10 \mathrm{mg} / \mathrm{kg}$ body weight). (A) Fas mRNA abundance was quantified by Q-RT-PCR. Shown are the mean ( \pm S.E.M.) $\beta$-actin normalized Fas mRNA abundances for the 3-, 6-, 12- and 24-h samples (gray bars) relative to the $0-\mathrm{h}$ sample (white bar). Bars with different letters are significantly different at $P<0 \cdot 05$. (B) There was a significant negative correlation between Fas mRNA abundance and percentage of neutrophils in blood of the dexamethasone-treated steers.

transcription by interfering with the action of other transcription factors, such as AP-1 or NF- $\mathrm{KB}$ (Scheinman et al. 1995, Bamberger et al. 1996, De Bosscher et al. 2003).
We observed that GR $\alpha$ was rapidly (4 h) lost in dosedependent fashion from the cytosol of dexamethasonetreated bovine neutrophils (Fig. 4B), without concurrent loss of GR $\alpha$ mRNA (data not shown). Therefore, the 
A

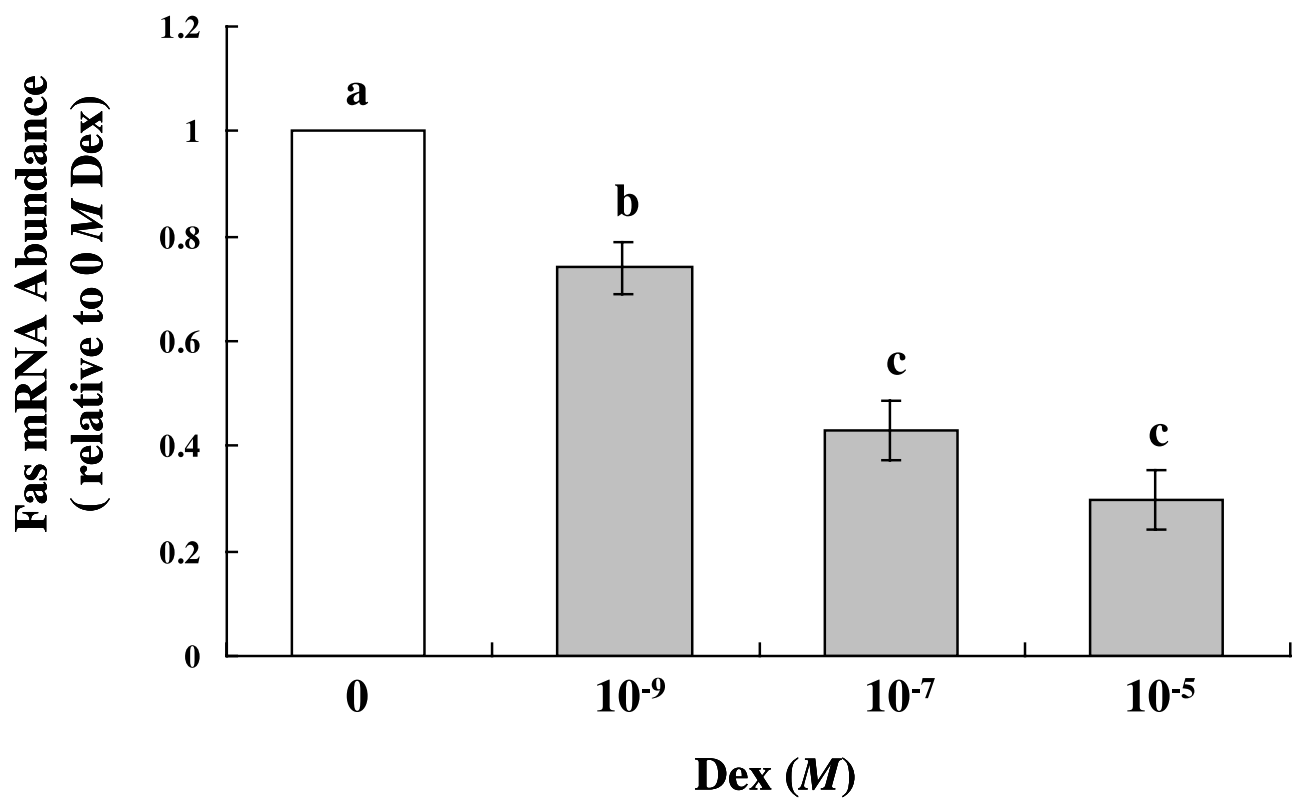

B

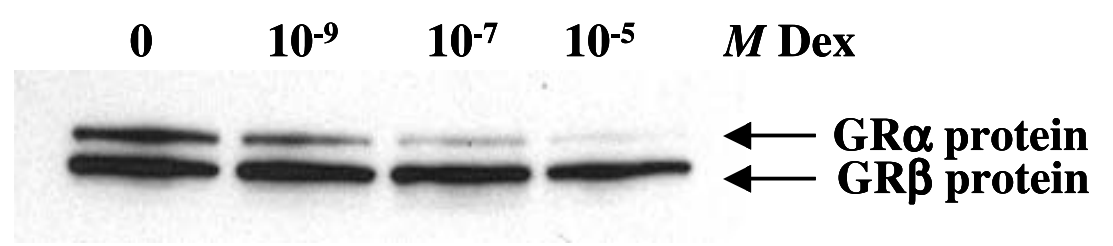

$\beta$-actin

Figure 4 Dexamethasone effects on Fas mRNA abundance in bovine neutrophils were direct and associated with loss of glucocorticoid receptor $\alpha(G R \alpha)$ from the cells' cytoplasm. Dexamethasone (Dex) caused a dose-dependent reduction of Fas mRNA abundance in isolated bovine blood neutrophils. The cells were cultured at $39^{\circ} \mathrm{C}$ in RPMI- 1640 medium containing $1 \%$ BSA and $0,10^{-9}, 10^{-7}$ or $10^{-5} \mathrm{M}$ Dex for $4 \mathrm{~h}$. (A) Fas mRNA abundance was quantified by Q-RT-PCR. Shown are mean ( \pm S.E.M.) $\beta$-actin normalized Fas mRNA abundances for the $10^{-9}, 10^{-7}$ or $10^{-5} \mathrm{M}$ Dex samples (gray bars) relative to the 0 M Dex sample (white bar). Bars with different letters are significantly different at $P<0 \cdot 05$. (B) Dex caused dose-dependent loss of GR $\alpha$ protein form the cytosol of treated bovine neutrophils. Shown is a representative immunoblot for purified blood neutrophils of one steer cultured as in (A). The cells were harvested and processed for isolation of cytosolic proteins, and the cytosols probed with an anti-GR antibody that recognizes GR $\alpha(97 \mathrm{kDa})$ and GR $\beta(94 \mathrm{kDa})$.

acute dexamethasone-induced decrease in GR $\alpha$ cytosolic proteins was probably not due to a limitation placed on GR $\alpha$ mRNA availability. Instead, ligand-activated GR $\alpha$ may have translocated into the nucleus to influence Fas gene expression in the neutrophils (Fig. 4A). This possibility was substantiated by our GR antagonism 


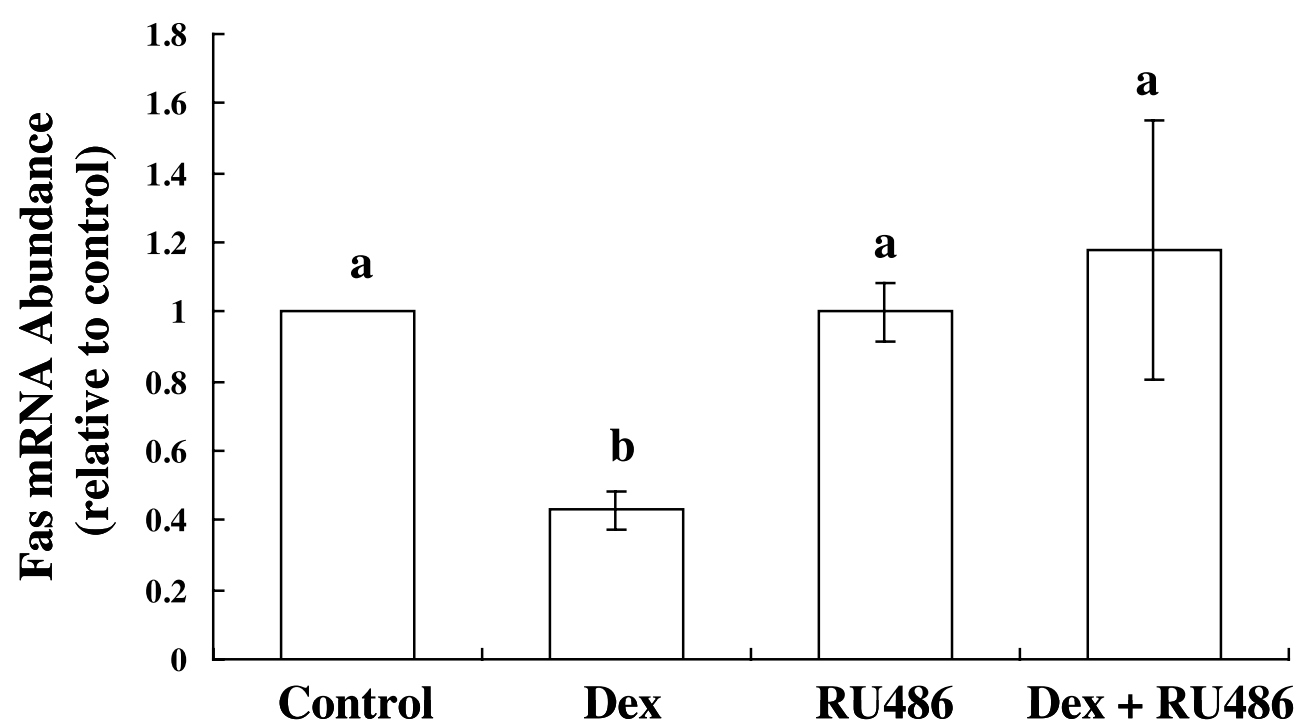

Figure 5 Dexamethasone (Dex)-induced downregulation of Fas mRNA abundance in isolated bovine blood neutrophils was inhibited by glucocorticoid receptor $\alpha(G R \alpha)$ antagonism. Isolated blood neutrophils from three steers were cultured at $39^{\circ} \mathrm{C}$ in basic culture medium for 10 min without $(0 \mathrm{M})$ and with $\left(10^{-4} \mathrm{M}\right)$ RU486, prior to an additional incubation $(4 \mathrm{~h})$ in medium alone (0 M Dex) or in medium containing $10^{-7} \mathrm{M}$ Dex. Fas mRNA abundance was quantified by Q-RT-PCR. Shown are mean ( \pm S.E.M.) $\beta$-actin normalized Fas gene expressions for the Dex, RU486 and RU486 \pm Dex-treated cells relative to untreated cells (control). Bars with different letters are significantly different at $P<0 \cdot 05$.

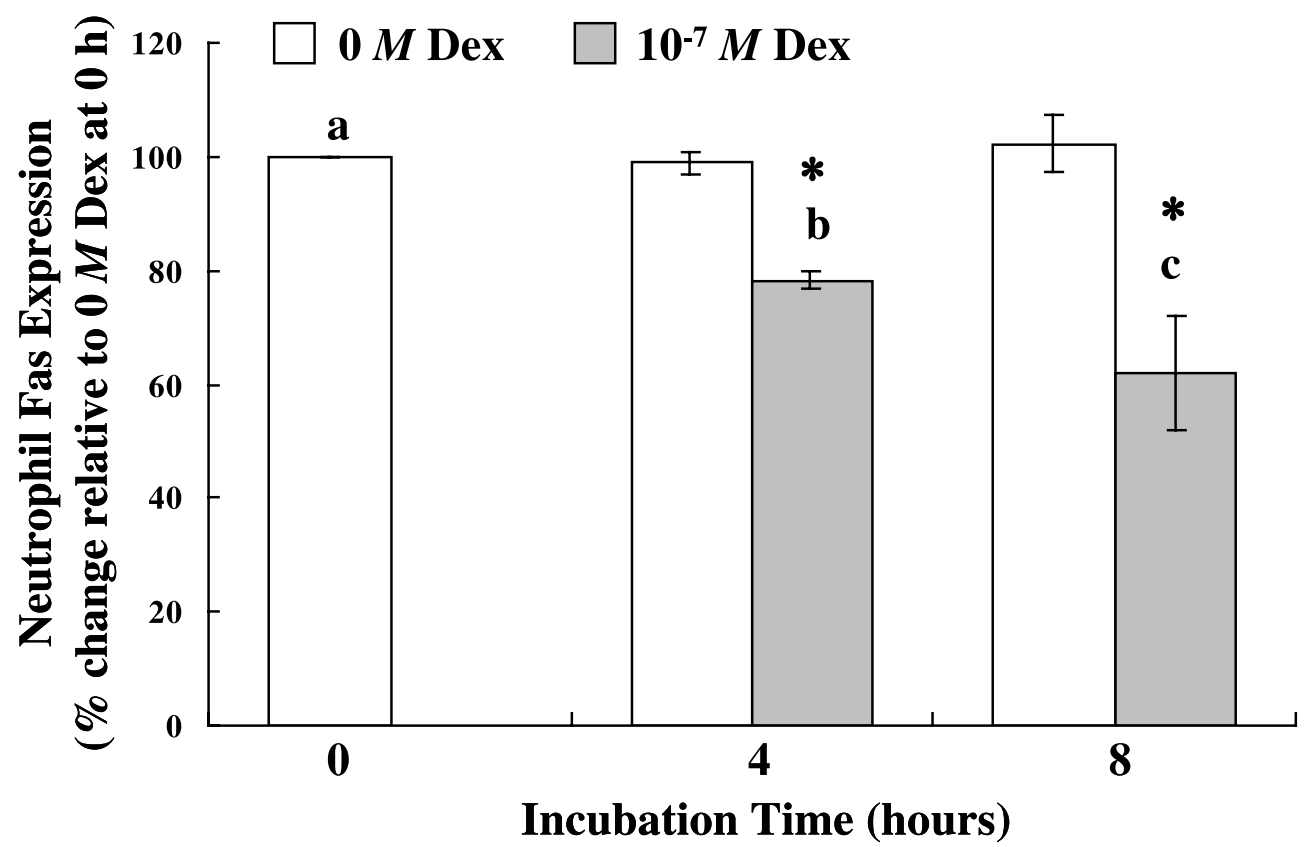

Figure 6 Dexamethasone (Dex) downregulated surface expression of Fas protein in cultured bovine neutrophils. Steer $(n=2)$ neutrophils were cultured in duplicate at $39{ }^{\circ} \mathrm{C}$ in RPMI-1640 medium and 0 or $10^{-7} \mathrm{M}$ Dex for 0,4 or $8 \mathrm{~h}$. Abundance of surface Fas protein was monitored by immunostaining (using an anti-Fas antibody and PE-conjugated secondary antibody) and fluorescence-activated flow cytometry. Data are mean ( \pm S.E.M.) percentage of changes in percent Fas ${ }^{+}$cells at 4 and $8 \mathrm{~h}$ relative to $0 \mathrm{~h}$. Bars with different letters are significantly different at $P<0 \cdot 05$. The 4- and 8-h bars with asterisks above them indicate significant differences between control (white bars) and Dex-treated (gray bars) neutrophils $(P<0 \cdot 05)$. 
$\mathbf{A}$

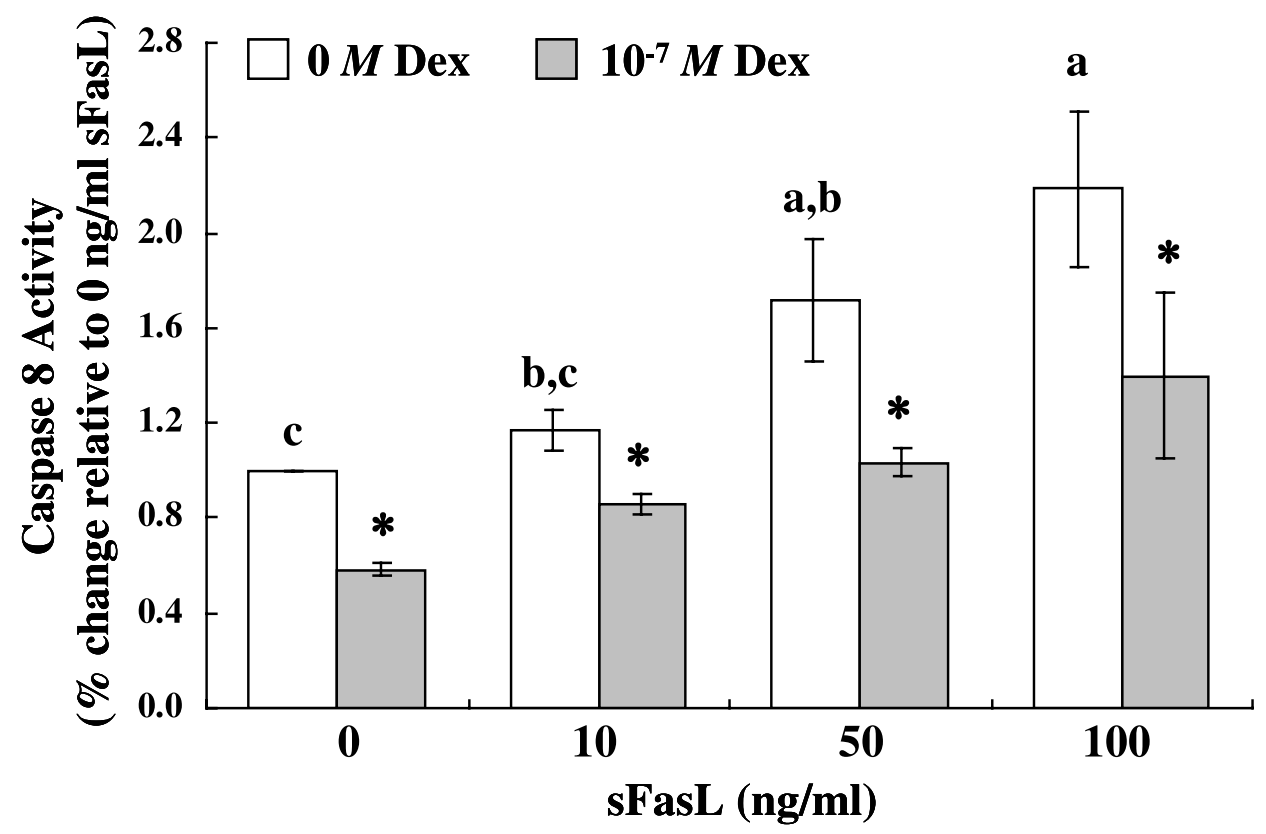

B

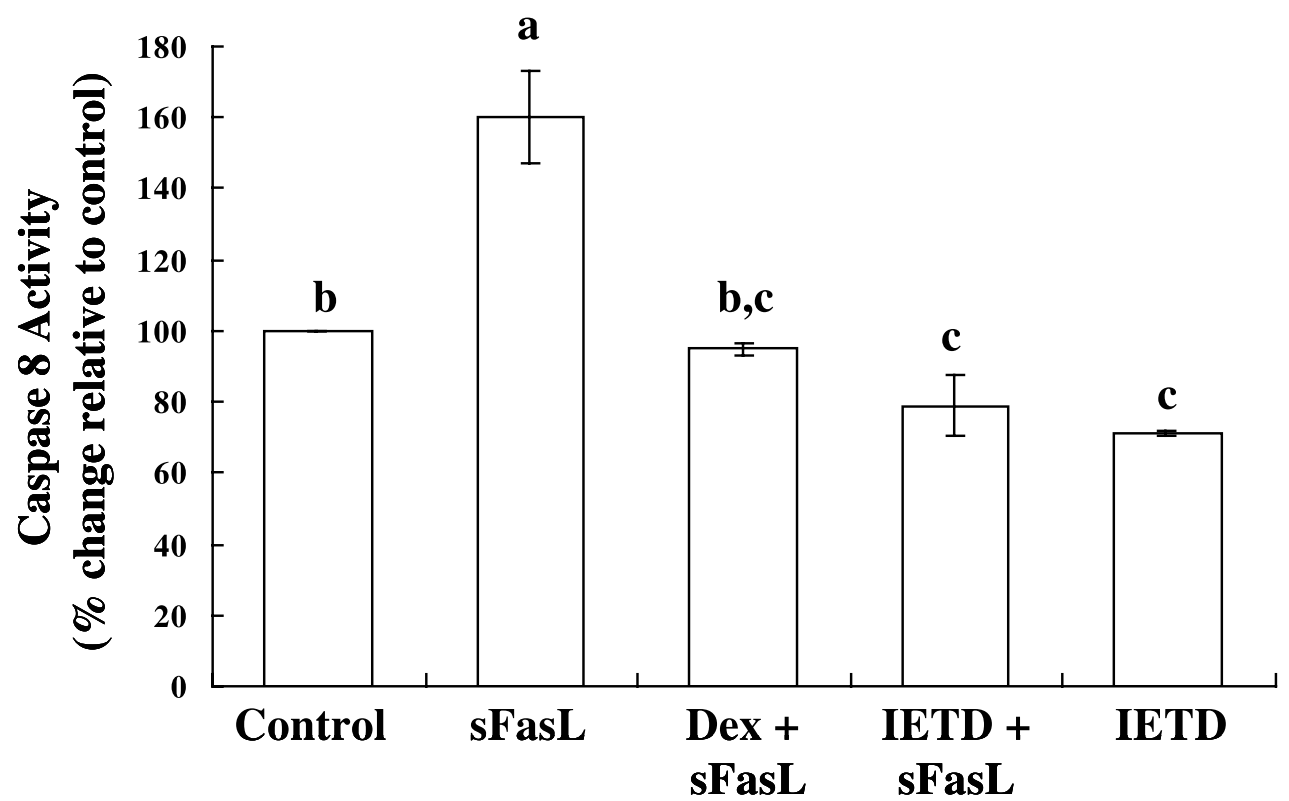

Figure 7 Dexamethasone (Dex) attenuates spontaneous and soluble FasL (sFasL)-induced caspase 8 activation. (A) Isolated neutrophils were cultured in duplicate at $39^{\circ} \mathrm{C}$ in RPMI-1640 medium containing $1 \%$ fetal bovine serum. Cells were preincubated with or without Dex $\left(10^{-7} \mathrm{M}\right)$ for $4 \mathrm{~h}$, and then incubated with various concentrations of sFasL $(0,10,50$ or $100 \mathrm{ng} / \mathrm{ml})$ for an additional $3 \mathrm{~h}$.

(B) Neutrophils were preincubated with $\pm 10^{-7} \mathrm{M}$ Dex for $4 \mathrm{~h}$ followed by sFasL $(100 \mathrm{ng} / \mathrm{ml})$ treatment for another $3 \mathrm{~h}$. Where indicated, cells were also treated with the caspase 8 inhibitor, z-IETD-fmk (IETD, $50 \mu \mathrm{M}$ ), which was added for 30 min before the addition of sFasL. Caspase 8 activity was measured with a commercial kit. Shown in both plots are means $( \pm$ S.E.M.) from two steers. Bars with different letters are significantly different at $P<0 \cdot 05$. 

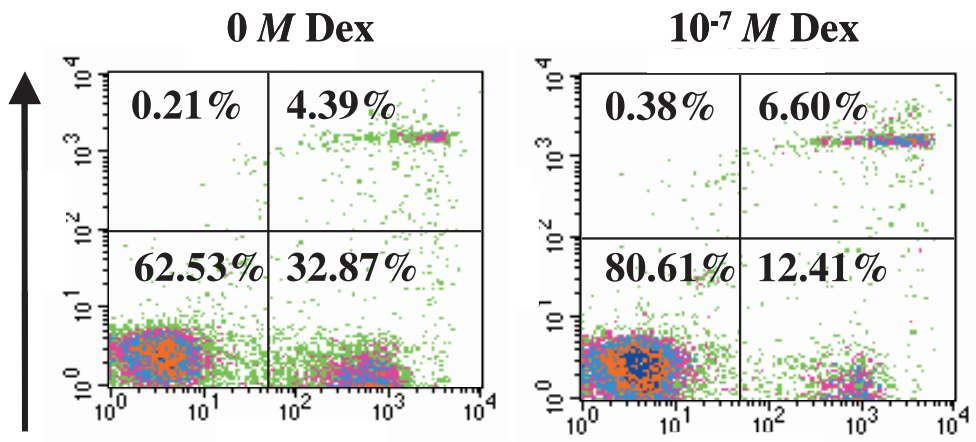

$7 \mathbf{h}$
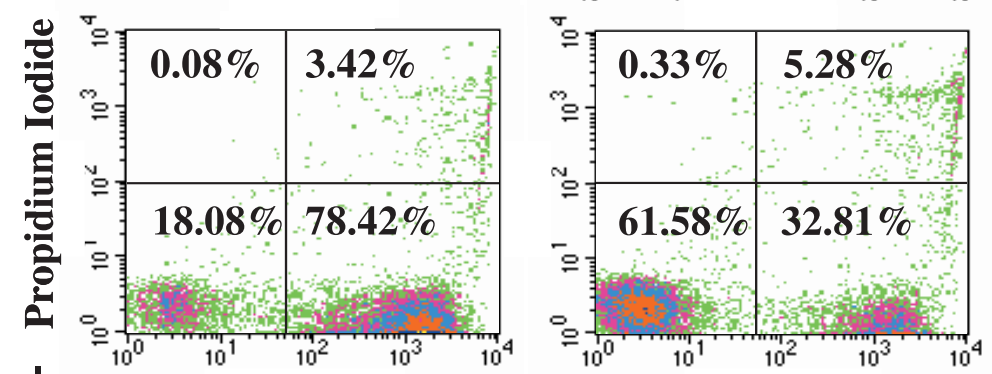

$12 \mathrm{~h}$
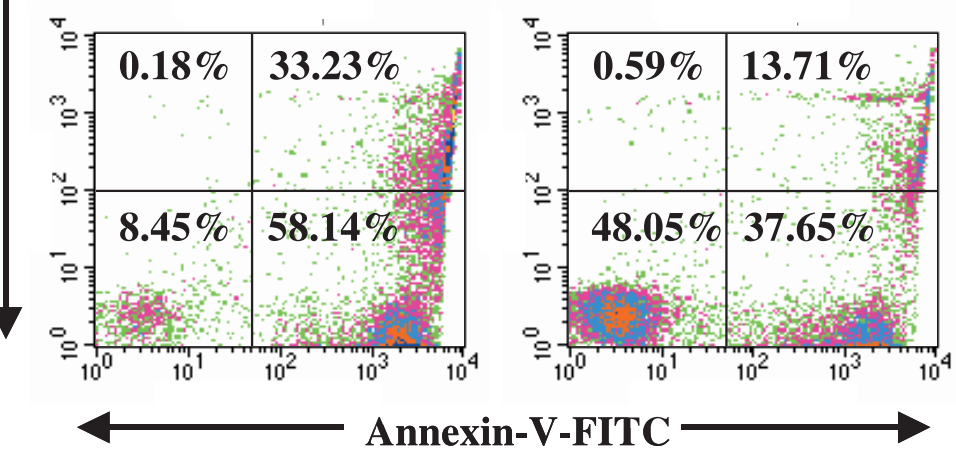

\section{$24 \mathrm{~h}$}

Figure 8 Dexamethasone (Dex) reduces the rate of spontaneous apoptosis in isolated bovine blood neutrophils. Neutrophils were cultured for 7,12 or $24 \mathrm{~h}$ with $\left(10^{-7} \mathrm{M}\right)$ or without (0 M) Dex and subjected to Annexin V-FITC/propidium iodide staining with two-color flow cytometric analysis to monitor apoptosis. Shown are representative two-color density dot plots for one steer, with Annexin V-FITC staining on the X-axes and propidium iodide staining on the $y$-axes. As shown by changes over time in the percentage of cells falling into the lower and upper right quadrants of these plots, Dex reduced the rate of apoptosis in cultured bovine neutrophils.

experiment, where RU486 (a potent antagonist of GR $\alpha$ ) inhibited dexamethasone-induced Fas mRNA downregulation in isolated blood neutrophils (Fig. 5). GR $\beta$ had no apparent involvement in the Fas response to dexamethasone because its cytosolic abundance did not change during the same $4 \mathrm{~h}$ of dexamethasone treatment (Fig. 4B).

The precise mechanism of GR $\alpha$ regulation of Fas gene expression is not known. While the presence of nGRE in the promoter of the human Fas gene has not been documented, NF- $\kappa \mathrm{B}$ and AP-1 binding sites are present, and the NF- $\mathrm{KB}$ and $\mathrm{AP}-1$ transcription factors participate directly in transcriptional regulation of human Fas (Cheng et al. 1995, Chan et al. 1999, Lasham et al. 2000). If the same is true in cattle, our in vivo and in vitro observations of glucocorticoid-induced downregulation of Fas gene expression in bovine neutrophils might be explained by GR $\alpha$ interference of NF- $\kappa B$ and AP-1. It is also possible that GR $\alpha$ interacts with Fas transcripts to affect their stability, as it does for $\mathrm{Bcl}-\mathrm{X}_{\mathrm{L} / \mathrm{S}}$ mRNA (an apoptosis regulator belonging to the $\mathrm{Bcl}-2$ family) (Chang et al. 1997). Yet another mechanism by which GR $\alpha$ may regulate Fas gene expression is through effects on new protein synthesis, as has been reported for FasL. In the FasL expression system, glucocorticoids inhibit activation-induced upregulation of FasL through induction of a separate glucocorticoid-induced gene, called the glucocorticoid-induced leucine zipper (GILZ) 
(Mittelstadt \& Ashwell 2001). We still do not know whether GR $\alpha$ regulation of Fas gene expression in bovine blood neutrophils is simple or complex.

Like a number of other proapoptotic proteins (such as Bad, Bax, Bak and Bik) (Moulding et al. 2001), surface Fas is constitutively expressed (Liles et al. 1996, Hsieh et al. 1997) and may have a relatively slow turnover rate in neutrophils. Thus, it may take longer for dexamethasone to change Fas protein expression than Fas mRNA abundance. This could explain why we observed relatively modest downregulation of surface Fas on neutrophils after 4 or $8 \mathrm{~h}$ of dexamethasone treatment in vitro (Fig. 6) compared with the pronounced decreases we observed in Fas mRNA abundance at $4 \mathrm{~h}$ of culture (Figs 4 and 5). However, even modest downregulation of surface Fas may be important biologically. A critical step in death signaling through Fas is activation of caspase 8 (Daigle \& Simon 2001), which activates caspase 3 to cause subsequent proteolysis and increased enzymatic activity of key deathinducing proteins (Khwaja \& Tatton 1999) that mediate plasma membrane instability, DNA fragmentation and cell death (Scaffidi et al. 1998, Schulze-Osthoff et al. 1998, Sharma et al. 2000, Zimmermann et al. 2001). Our in vitro experiments showed that dexamethasone attenuated spontaneous caspase 8 activity and dramatically slowed the rate of spontaneous neutrophil apoptosis (Figs 7 and 8). This suggested to us that Fas downregulation may have played a role in extending the longevity of glucocorticoidtreated neutrophils. However, the results of a recent study question the involvement of Fas signaling during spontaneous apoptosis of neutrophils in culture (Daigle \& Simon 2001). Accordingly, we repeated our in vitro experiment using sFasL to induce caspase 8 activation through Fas signaling, and included a specific inhibitor of caspase 8 (z-IETD-fmk) as a negative control. We showed that dexamethasone was as effective as z-IETDfmk in decreasing sFasL-induced caspase 8 activation in bovine blood neutrophils (Fig. 7). We thus propose that glucocorticoid-induced downregulation of Fas gene and protein expression were upstream events that impinged on this apoptosis signaling pathway, possibly influencing the ability of the death-inducing signaling complex to form, recruit and activate caspase 8 . In substantiation of this proposition, alternations in Fas expression are known to change the sensitivity of a human myeloma cell line and eosinophils to FasL-mediated apoptosis (Luttmann et al. 1998, Shain et al. 2000). Thus, while it is possible that glucocorticoids also affect the expression or activity of other proteins involved in spontaneous apoptosis, our current results implicate Fas downregulation as one event that could explain the steroid's ability to reduce FasLmediated caspase 8 activation and apoptosis in neutrophils. We did not directly measure caspase 8 activity or apoptotic status of blood neutrophils from our periparturient cows or dexamethasone-treated steers, but we did observe strong negative correlations between Fas gene expression and circulating numbers of blood neutrophils in these animals (Figs 1-3). Thus, we hypothesize that Fas downregulation, reduced caspase 8 activity and extended cell survival also occurred in circulating neutrophils in vivo during the surge in parturient cortisol and after dexamethasone administration.

\section{Conclusion}

We conclude from the in vivo and in vitro results of this study that Fas gene expression in bovine blood neutrophils is regulated by GR $\alpha$-mediated events when the cells are exposed to physiologic and pharmacologic levels of glucocorticoids, and that this leads to attenuated caspase 8 activity and extended longevity of the cells.

\section{Acknowledgements}

Many thanks are due to Anders Toelboell, Marie-Clare Hickey and Kelly Buckham for their assistance with animal handling and blood collection, and to Bob Kreft and his staff at the MSU Dairy Teaching and Research facility for their excellent care of the cows and steers used in this study. This work was supported in part by funds from the Michigan Agricultural Experiment Station for JLB's participation in USDA Multistate Research Project NC-209 (project no. MICL01691), and by USDA-IFAFS grant no. 2001-52100-11211. The authors declare that there is no conflict of interest that would prejudice the impartiality of this scientific work.

\section{References}

Bamberger CM, Schulte HM \& Chrousos GP 1996 Molecular determinants of glucocorticoid receptor function and tissue sensitivity to glucocorticoids. Endocrine Review 17 245-261.

Chan H, Bartos D \& Owen-Schaub LB 1999 Activation-dependent transcriptional regulation of the human fas promoter requires NF-кB p50-p65 recruitment. Molecular and Cellular Biology 19 2098-2108.

Chang TC, Hung MW, Jiang SY, Chu JT, Chu LL \& Tsai LC 1997 Dexamethasone suppresses apoptosis in a human gastric cancer cell line through modulation of bcl-x gene expression. FEBS Letters 415 11-15.

Cheng J, Liu C, Koopman WJ \& Mountz JD 1995 Characterization of human Fas gene. Journal of Immunology 154 1239-1245.

Collingwood TN, Unnov FD \& Wolffe AP 1999 Nuclear receptors: coactivators, corepressors and chromatin remodeling in the control of transcription. Journal of Molecular Endocrinology 23 255-275.

Cox G 1995 Glucocorticoid treatment inhibits apoptosis in human neutrophils: separation of survival and activation outcomes. Journal of Immunology 154 4719-4725.

Coxon A, Tang T \& Mayadas TN 1999 Cytokine-activated endothelial cells by delay neutrophil apoptosis in vitro and in vivo: a role for granulocyte/macrophage colony-stimulating factor. Journal of Experimental Medicine 190 923-933.

Daffern PJ, Jagels MA \& Hugli TE 1999 Multiple epithelial cell-derived factors enhance neutrophil survival: regulation by glucocorticoids and tumor necrosis factor- $\alpha$. American Journal of Respiratory Cell and Molecular Biology 21 259-267. 
Daigle I \& Simon HU 2001 Critical role for caspases 3 and 8 in neutrophil but not eosinophil apoptosis. International Archives of Allergy and Immunology 126 147-156.

De Bosscher K, Vanden Berghe W \& Haegeman G 2003 The interplay between the glucocorticoid receptor and nuclear factor-kappaB or activator protein-1: molecular mechanisms for gene repression. Endocrinology Review 24 488-522.

Dibbert B, Weber M, Nikolaizik WH, Vogt P, Schoni MH, Blaser K \& Simon HU 1999 Cytokine-mediated Bax deficiency and consequent delayed neutrophil apoptosis: a general mechanism to accumulate effector cells in inflammation. PNAS 96 13330-13335.

Droulin J, Trifiro A, Plante RK, Nemer M, Eriksson P \& Wrange O 1989 Glucocorticoid receptor binding to a specific DNA sequence is required for hormone-dependent repression of pro-opiomolanocortin gene transcription. Molecular and Cellular Biology 9 5305-5314.

Fanning NF, Redmnd HP \& Bouchier-Hayes D 1999 Neutrophils and apoptosis. In The Neutrophils: New Outlook for Old Cells, pp 231-242. Ed. DI Gabrilovich. London: Imperial College Press.

Haslett C 1999 Granulocyte apoptosis and its role in the resolution and control of lung inflammation. American Journal of Respiratory and Critical Care Medicine 160 S5-S11.

Heasman SJ, Giles KM, Ward C, Rossi AG, Haslett C \& Dransfield I 2003 Mechanisms of steroid action and resistance in inflammation. Glucocorticoid-mediated regulation of granulocyte apoptosis and macrophage phagocytosis of apoptotic cells: implication for the resolution of inflammation. Journal of Endocrinology 178 29-36.

Hsieh SC, Huang MH, Tsai CY, Tsai YY, Tsai ST, Sun KH, Yu HS, Han SH \& Yu CL 1997 The expression of genes modulating programmed cell death in normal human polymorphonuclear neutrophils. Biochemical and Biophysical Research Communications 233 700-706.

Khwaja A \& Tatton L 1999 Caspase-mediated proteolysis and activation of protein kinase $\mathrm{C} \delta$ play a central role in neutrophil apoptosis. Blood 94 291-301.

Kino T, Stauber RH, Resau JH, Pavlakis GN \& Chrousos GP 2001 Pathologic human GR mutant has a transdominant negative effect on the wild-type GR by inhibiting its translocation into the nucleus: importance of the ligand-binding domain for intracellular GR trafficking. Journal of Clinical Endocrinology and Metabolism 86 $5600-5608$.

Kuijpers TW 2002 Clinical symptoms and neutropenia: the balance of neutrophil development, functional activity, and cell death. European Journal of Pediatrics 161 S75-S82.

Lasham A, Lingridge E, Rudert F, Onrust R \& Watson J 2000 Regulation of the human fas promoter by YB-1, Pur $\alpha$ and AP-1 transcription factors. Gene 252 1-13.

Liles WC, Dale DC \& Klebanoff SJ 1995 Glucocorticoids inhibit apoptosis of human neutrophils. Blood 86 3181-3188.

Liles WC, Kener PA \& Ledbetter JA 1996 Differential expression of Fas (CD95) and Fas ligand on normal human phagocytes: implications for the regulation of apoptosis in neutrophils. Journal of Experimental Medicine 184 429-440.

Lin EY, Orlofsky A, Wang H-G, Reed JC \& Prystowsky MB 1996 A1, a Bcl-2 family member, prolongs cell survival and permits myeloid differentiation. Blood 87 983-992.

Livak KJ \& Schmittgen TD 2001 Analysis of relative gene expression data using real-time quantitative PCR and the $2^{-\Delta \Delta C} \mathrm{~T}$ method. Methods 25 402-408.

Luttmann W, Opfer A, Dauer E, Foerster M, Matthys H, Eibel H, Schulze-Osthoff K, Kroegel C \& Virchow JC 1998 Differential regulation of CD95 (Fas/APO-1) expression in human blood eosinophils. European Journal of Immunology 28 2057-2065.

Madsen SA, Chang LC, Hickey M, Rosa GJM, Coussens PM \& Burton JL 2004 Microarray analysis of gene expression in blood neutrophils of parturient cows. Physiological Genomics 16 212-221.
Meagher LC, Cousin JM, Seckl JR \& Haslett C 1996 Opposing effects of glucocorticoids on the rate of apoptosis in neutrophilic and eosinophilic granulocytes. Journal of Immunology $1564422-4428$.

Mittelstadt PR \& Ashwell JD 2001 Inhibition of AP-1 by the glucocorticoid-inducible protein GILZ. Journal of Biological Chemistry 276 29603-29610.

Moulding DA, Akgul C, Derouet M, White MRH \& Edwards WW 2001 BCL-2 family expression in human neutrophils during delayed and accelerated apoptosis. Journal of Leukocyte Biology 70 783-792.

Moulding DA, Quayle JA, Hart A \& Edward SW 1998 Mcl-1 expression in human neutrophils: regulation by cytokines and correlation with cell survival. Blood 92 2495-2502.

Nambu Y, Hughes SJ, Rehemtulla A, Hamstra D, Orringer MB \& Beer DG 1998 Lack of cell surface Fas/APO-1 expression in pulmonary adenocarcinomas. Journal of Clinical Investigation 101 1102-1110.

Nittoh T, Fuimori H, Kozumi Y, Ishihara K, Mue S \& Ohuchi K 1998 Effects of glucocorticoid on apoptosis of infiltrated eosinophils and neutrophils in rats. European Journal of Pharmacology 354 73-81.

O’Donnell DR, Milligan L \& Stark JM 1999 Induction of CD95 (Fas) and apoptosis in respiratory epithelial cell cultures following respiratory syncytial virus infection. Virology 257 198-207.

Pujols L, Mullol J, Roca-Ferrer J, Torrego A, Xaubet A, Cidlowski JA \& Picado C 2002 Expression of glucocorticoid receptor alpha- and beta-isoforms in human cells and tissues. American Journal of Physiology: Cell Physiology 283 C1324-C1331.

Robertson JD, Orrenius S \& Zhivotovsky B 2000 Review: nuclear events in apoptosis. Journal of Structural Biology 120 346-358.

SAS Institute 1990 SAS Procedures Guide, 3rd edn, version 6, pp. 209-234. Cary, NC: SAS Institute.

SAS Institute 1996 SAS/STAT software: changes and enhancement through release 6.11, pp 531-656. Cary, NC: SAS Institute.

Scaffidi C, Fulda S, Srinivasan A, Friesen C, Li F, Tomaselli KJ, Debatin KM, Krammer PH \& Peter ME 1998 Two CD95 (APO-1/Fas) signaling pathways. EMBO Journal 17 1675-1687.

Scheinman RL, Gualberto A, Jewell CM, Cidlowski JA \& Baidwin AS Jr 1995 Characterization of mechanisms involved in transrepression of NF-kappa B by activated glucocorticoid receptors. Molecular and Cellular Biology 15 943-953.

Schulze-Osthoff K, Ferrari D, Los M, Wesselborg S \& Peter ME 1998 Apoptosis signaling by death receptors. European Journal of Biochemistry 254 439-459.

Sendo F, Tsuchida H, Takeda Y, Gon S, Takei H, Kato T, Hachiya O \& Watanabe H 1996 Regulation of neutrophil apoptosis - its biological significance in inflammation and the immune response. Human Cell 9 215-221.

Shain KH, Landowski TH, Buyuksal I, Cantor AB \& Dalton WS 2002 Clonal variability in CD95 expression is the major determinant in Fas-medicated, but not chemotherapy-medicated apoptosis in the RPMI 8226 multiple myeloma cell line. Lenkemia 14 830-840.

Sharma K, Wang RX, Zhang LY, Yin DL, Luo XY, Solomon JC, Jiang RF, Markos K, Davidson W, Scott DW \& Shi YF 2000 Death the Fas way: regulation and pathophysiology of CD95 and its ligand. Pharmacology and Therapeutics 88 333-347.

Strickland I, Kisich K, Hauk PJ, Vottero A, Chrousos GP, Klemm DJ \& Leung DY 2001 High constitutive glucocorticoid receptor beta in human neutrophils enables them to reduce their spontaneous rate of cell death in response to corticosteroids. Journal of Experimental Medicine 19 3585-3593.

Webb PR, Wang KQ, Scheel-Toellner D, Pongracz J, Salmon M \& Lord JM 2000 Regulation of neutrophil apoptosis: a role for protein kinase C and phosphatidylinositol-3-kinase. Apoptosis 5 451-458.

Weber PS, Toelboell T, Chang LC, Tirrell JD, Saama PM, Smith GW \& Burton JL 2004 Mechanisms of glucocorticoid-induced down-regulation of neutrophil L-selectin in cattle: evidence for effects at the gene-expression level and primarily on blood neutrophils. Journal of Lenkocyte Biology 75 815-827. 
Weber PSD, Madsen SA, Smith GW, Ireland JJ \& Burton JL 2001 Pre-translational regulation of neutrophil L-selectin in glucocorticoid-challenged cattle. Veterinary Immunology and Immunopathology 83 213-240.

Weyts FAA, Flik G, \& Verburg-van Kemenade BML 1998 Cortisol inhibits apoptosis on carp neutrophilic granulocytes. Developmental and Comparative Immunology 22 563-572.

Whyte MKB, Meagher LC, MacDermot J \& Haslett C 1993 Impairment of function in aging neurophils is associated with apoptosis. Journal of Immunology 150 5124-5134.
Yoo J, Stone RT, Kappes SM, Toldo SS, Fries R \& Beattie CW 1996 Genomic organization and chromosomal mapping of the bovine Fas/APO-1 gene. DNA and Cell Biology 15 377-385.

Zimmermann KC, Bonzon C \& Green DR 2001 The machinery of programmed cell death. Pharmacology and Therapeutics 92 57-70.

Received in final form 14 August 2004

Accepted 18 August 2004

Made available online as an

Accepted Preprint 26 August 2004 